\title{
FREEDOM OF EXPRESSION AND CAMPUS PROTESTS
}

"What is the difference between a repressive totalitarian state and a state with liberal democratic laws whose citizens do not respect the freedoms such laws guarantee? Nothing. A country can have the most liberal freedom of speech and association in the world, but if its citizens are not animated by the spirit of the laws, if they do not believe in them, then those laws are dead letters".

Stephen Chavura - The Australian (6-4-17) 11

\section{Introduction}

Hotz v University of Cape Town (2016 (4) All SA 723 (SCA)) presented the Supreme Court of Appeal (SCA) with an ideal set of circumstances to incisively deal with the precise meaning and parameters of section 16(1) of the Constitution, which mandates that everyone has the right to freedom of expression and section 16(2), which states that section 16(1) does not extend to advocacy of hatred that is based on race or ethnicity and that constitutes incitement to cause harm. It also afforded the SCA an opportunity to express itself on ancillary constitutional rights such as section 17 (the right to assemble and demonstrate); section 15 (the right of freedom of opinion); section 18 (the right to freedom of association) and section 19(1) (the right to campaign for a political cause). (S 15, 17, 18 and 19 are incisively discussed by Rautenbach in Rautenbach - Malherbe Constitutional Law (2012) 369-385). The main focus of the judgment of the SCA (per Wallis JA), however, was on freedom of expression (s 16(1)) which will be the primary focus of this note.

Vehement protests on the campus of the University of Cape Town (UCT) constituted the background to this matter being heard by the SCA as an appeal against a final interdict of the Western Cape High Court. The final interdict excluding appellants from the campus of UCT was granted by Allie $J$ who granted leave to appeal. The appeal specifically concerned the granting of the final interdict and the factual allegations made by the university regarding the nature of the protests which led to the granting of the final interdict.

\section{The factual background}

The background to the serious constitutional law issues raised in the appeal to the SCA can briefly be summarized as follows: The wave of student protests, which commenced on South African university campuses in March 2015 and were conducted under names such as \#RhodesMustFall and \#FeesMustFall reached a climax on the campus of UCT from 15 to 17 February 2016. The protests focused on the difficulties experienced by 
mainly black students to pay the university fees; problems finding suitable accommodation to enable black students to pursue their studies; transforming UCT from what the students perceived as its colonial and Eurocentric heritage and the problems affecting poor people in obtaining decent housing. The protests on the UCT campus were manifested in various ways, including building a shack on the campus in the middle of a busy road significantly obstructing traffic and pedestrians. Prominently displayed on the ground in front of the shack was a sign "Rhodes must Fall" and on the shack the words "UCT Housing Crisis".

Slogans were painted on the war memorial, which commemorated persons with a connection to UCT who died in World Wars I and II which read "Fxxx White People"; "1652 must go"; "UCT is a Site of Conquest"; "UCT lyakaka moer" and "Fxxx Black Exclusion". Slogans reading "Fxxx White people" and "Fxxx White tears" were painted on the pavement where a shuttle bus collects students from a residence on the lower campus to take them to the upper campus.

Attempts by UCT management to invoke the assistance of the police were unsuccessful and a letter from UCT recognizing the protesters' right to protest and offering assistance to remove the shack was torn up in the presence of the university's management. Twenty-five works of art having a value of nearly R700,000-00 were set alight - besides many formal historical photographs being destroyed. A vehicle used for research purposes and a shuttle bus to the combined value of R1.6 million were set alight and destroyed. An incendiary device thrown through the window of the office of the Vice-Chancellor of UCT caused damage estimated at R350,000-00. A posting on social media threatened to "burn books written by white people" in the university library.

On these factual grounds, the High Court granted UCT a final interdict to the effect that appellants were excluded from the campus. It was against this final interdict that appellants appealed to the SCA. This led to the SCA's view's on protest action in its broader sense and the Constitution's imperatives in that regard.

\section{The judgment}

The SCA (Navsa, Bosielo, Theron and Mathopo JJA) concurred in the judgment of Wallis JA who held (par 62) that protest action is not itself unlawful as pointed out by Skweyiya $\mathrm{J}$ in Pilane $v$ Pilane (2013 (4) BCLR 431 par 38) and the right to protest against injustice is protected in the Constitution in section 17 (the right to assemble, demonstrate and present petitions); section 16(1) (the right of freedom of expression); section 18 (the right of freedom of association) and section 19(1) (the right to make political choices and campaign for a political cause). However, held Wallis JA (par 62 ), the mode of the exercise of those rights is also subject to constitutional regulation. Just as the right to freedom of expression does not extend to the advocacy of hatred that is based on race or ethnicity and constitutes incitement to harm (s 16(2)(c)); the right of demonstration is to be exercised peacefully and unarmed ( $\mathrm{s} 17)$; all rights are to be exercised in a manner 
that respects and protects the foundational value of human dignity of other people (s 10) and the rights other people enjoy under the Constitution.

He held further that in a democracy, all rights vested in one person or group necessitates the recognition of the rights of other persons and groups and people must recognize this when exercising their own constitutional rights (par 62). In this regard, Wallis JA referred to Mogoeng CJ in SATAWU v Garvis (2013 (1) SA 83 (CC) par 68) where he held that "every right must be exercised with due regard to the rights of others". Wallis JA (par 63) also referred extensively to the SCA decision in SATAWU v Garvis (2011 (6) SA 382 (SCA) par 47-49) where it was held:

"Our Constitution saw South Africa making a clean break with the past. The Constitution is focused on ensuring human dignity, the achievement of equality and the advancement of human rights and freedoms. It is calculated to ensure accountability, responsiveness and openness. Public demonstrations and marches are a regular feature of present day South Africa. I accept that assemblies, pickets, marches and demonstrations are an essential feature of a democratic society and that they are essential instruments of dialogue in society. The [Regulation of Gatherings] Act was designed to ensure that public protests and demonstrations are confined within legally recognized limits with due regards for the rights of others.

I agree with the court below that the rights set out in s 17 of the Constitution, namely, the rights to assemble and demonstrate, are not implicated because persons engaging in those activities have the right to do so only if they are peaceful and unarmed. It is that kind of demonstration and assembly that is protected. Causing and participating in riots are the antithesis of constitutional values. Liability in terms of $s 11$ follows on the unlawful behaviour of those participating in a march. The court below rightly had regard to similar wording in the Constitution of the United States, where people are given the right to assemble peacefully. Such provisions in constitutions such as ours are deliberate. They preclude challenges to statutes that restrict unlawful behaviour in relation to gatherings and demonstrations that impinge on the rights of others.

It was submitted on behalf of the Union that damage to public property caused by a gathering that degenerated into a riot was a small price to pay to preserve and protect the precious rights to public assembly and protests, which is integral to a democratic state. I agree with the court below that members of the public are entitled to protection against behaviour that militates against the rule of law and the rights of others."

Applying above legal exposition regarding protest action to the facts of the case Wallis JA in essence held: (a) The blocking of the road on the UCT campus caused great inconvenience and could have contributed to confrontations arising and led to threatening behaviour; (b) the spray painting and defacing of UCT property and the war memorial and the burning of portraits and photographs constituted the criminal offence of malicious injury to property; (c) slogans on the war memorial and on Tshirts went beyond a passionate expression of feelings and views and became the advocacy of hatred based on race or ethnicity and constituted an incitement to cause harm. It thereby lost its constitutional protection. Langa CJ in Islamic Unity Convention $v$ Independent Broadcasting Authority (2002 (4) SA 294 (CC) par 32) succinctly explained the reason for this emphasizing section 16(2) of the Constitution, which states that the 
freedom of expression referred to in section 16(1) does not extend to advocacy of hatred:

\begin{abstract}
"Section 16(2) therefore defines the boundaries beyond which the right to freedom of expression does not extend. In that sense, the subsection is definitional. Implicit in its provisions is an acknowledgement that certain expression does not deserve constitutional protection because, among other things, it has the potential to impinge adversely on the dignity of others and cause harm. Our Constitution is founded on the principles of dignity, equal worth and freedom, and these objectives should be given effect to."
\end{abstract}

The words on a T-shirt that all whites should be killed, Wallis JA (par 68) held, should be interpreted on its face value and was the advocacy of hatred based on race alone and constituted incitement to harm whites. It was thus not speech protected by section 16(1) of the Constitution. The slogan "Fxxx White People" painted on the war memorial Wallis JA however, (par 69) saw as nothing more than a crudely worded slogan, which does not necessarily operate as an inducement to cause them harm.

Appellants contended that their conduct was necessary in the light of UCT's failure to address their concerns and the lack of transformation of which they complained. This contention of necessity failed. Firstly, held Wallis JA (par 72), because the defence of necessity was never raised in the affidavits and none of the appellants had alleged that they had acted out of necessity. Secondly, the appellants' actions amounting to civil disobedience were not necessary, as there was no unjust or oppressive political and legal system present under South Africa's present constitutional dispensation. As seen by Wallis JA (par 72) the actions of the appellants were not on par with the civil disobedience acts of Mahatma Gandhi, Martin Luther King, Archbishop Desmond Tutu and Rosa Parks (an African American who sat on a seat reserved for white people). The actions of these people held Wallis JA (par 72), had a moral content contrary to the actions of the appellants' actions on the UCT campus.

The appeal thus failed and it follows that the UCT was entitled to the final interdict. The broad terms of the interdict, however, effectively excluding appellants from the university campus was however, amended so as not to infringe on their rights of freedom of movement and freedom of association and was limited to interdicting them against unlawful conduct on the university's premises.

For purposes of comparison, it would however not be inopportune to comment on the approaches to freedom of expression - referred to as freedom of speech - in a country without a Bill of Rights such as Australia, a country with a Bill of Rights such as the United States of America and the relevant international and regional human rights instruments.

\title{
4
}

\section{Australia}

In Australia freedom of expression, referred to as freedom of speech, does not rely on a broad and entrenched constitutional or statutory protection such as for example in a Bill of Rights but more on a common law tradition (Chesterman Freedom of Speech in Australian Law (2000); Gelber 
"Pedestrian Malls, Local Government and Free Speech Policy" 2003 Policy and Society 22 49). This common law protection of freedom speech has been strong enough to have a significant influence on the reach of free speech and the policy regarding hate speech (McNamara Regulating Racism: Racial Vilification Laws in Australia (2002)).

Freedom of speech thus exists because of the unshakeable faith in parliamentary democracy (Winterton Australian Federal Constitutional Law (2007) 604 662) and is as a consequence implied in the nature of representative government (Ratnapala and Crowe Australian Constitutional Law (2012) 381 414; Brookshield and Williams Australian Constitutional Law and Theory (2006) 1291). This view has been affirmed in Lange $v$ Australian Broadcasting Corporation ((1997) 189 CLR 520); Nationwide News (Pty) Ltd $v$ Wills ((1992) 177 CLR 121) and Australian Capital Television (Pty) Ltd v Commonwealth ((1992) 177 CLR 106). In Nationwide News, Deane and Toohey JJ (par 74) held that "Inherent in the Constitution's doctrine of representative government is an implication of the freedom of the people of the Commonwealth to communicate information, opinions and ideas about all aspects of the government of the Commonwealth". In Australian Capital Television (Pty) Ltd v Commonwealth, supra Mason CJ (par 139) held that "Freedom of communication is an indispensable element of representative government".

This implied freedom of speech in effect, operates as a freedom from government restraint rather than as a right conferred on individuals (Williams Rights Under the Australian Constitution (2002) 165-197; Stone "Rights, Personal Rights and Freedoms" 2001 Melbourne University LR 374 418; Ratnapala and Crowe Australian Constitutional Law 421; Theopanus $V$ Herald; Weekly Times (1992) 182 CLR 104 168; Cunliffe $v$ Commonwealth (1994) 182 CLR 272 326).

This implied freedom of speech has also manifested itself strongly in what is known as "political communication" which condones free discussions which have a bearing on politics. However, such "political communication" could be restricted by a law which is intended to achieve a legitimate government end. This is known as the "Lange" test derived from the case of Lange Australian Broadcasting Corporation, where it was held (567) that such a law must be reasonably appropriate to serve a legitimate end, the fulfilment of which is compatible with the maintenance of the constitutionally prescribed system of representative and responsible government (see Coleman v Power (2004) 220 CLR 1 66). In this climate, anti-hate speech laws have become accepted and in every state, the Australian Capital Territory, and on a federal level, anti-vilification laws exist. These laws have the effect that in Australia hate speech is an unacceptable form of expression which warrants government intervention. An example is the federal Racial Discrimination Act 1975 (Cth) (s 18B-18F) the full impact of which is set out in Koowarta v Bjelke-Petersen ((1982) 153 CLR 168).

The grounds on which complaints of vilification may be lodged range from race, religion, HIV/AIDS status, gender identity, sexuality and disability. Penalties can range from civil only, to criminal only to civil and criminal. In Western Australia, for example, only criminal provisions are in force. 
Although the High Court has yet to decide on the constitutionality of anti-hate speech laws, attempts to submit that hate speech is part and parcel of freedom of speech have failed in the lower courts (Islamic Council of Victoria $v$ Catch the Fire Ministries Inc (2006) VSCA 284). Laws limiting hate speech are thus not seen to hinder the extent of the protection of freedom of speech in Australia.

Since Coleman $v$ Power supra a more restrictive approach to implied freedom of political communication has also been adopted following the majority of the High Court's decision (par 76) that insults may be political communication only if they are intended to make a political point and are not likely to provoke violence. This restrictive approach, similar to hate speech limiting laws, is also not seen to hinder the extent of the implied freedom of speech in Australia (Gelber "Freedom of Political Speech" 2010 Contemporary Political Theory 304 324).

At present (2017) the Turnbull government has announced that it intends to propose changes to section $18 \mathrm{C}$ of the Racial Administration Act that at present makes it unlawful to engage in acts that are "reasonably likely" to "offend, insult, humiliate or intimidate" someone because of their ethnicity or race. Under the proposal, the word "harass" will replace the words "offend, insult or humiliate". A provision will also be included saying that the test to be applied in deciding whether section $18 \mathrm{C}$ has been breached is the objective standard of "the reasonable member of the Australian community."

This proposal has caused some debate as to how it is going to affect the various hate speech laws - if any. If it is going to have no significant effect, the question arises why come with the proposals? A further question is why introduce the word "harass" where "vilify" or "degrade" may have been a better option? The definition of "the reasonable member of the Australian community" may also be problematic.

Is "the reasonable member of the Australian community" someone who is sensitive to minority concerns? According to Wesson (The Conversation (174-51), the proposed changes may confuse rather than clarify the meaning of section $18 \mathrm{C}$ and are likely to be blocked by the Senate.

\section{$5 \quad$ The United States of America}

The United States has developed a strong tradition of freedom of expression, referred to as freedom of speech, which protects even the most offensive forms of expression. The First Amendment, which is the first clause of the Bill of Rights, protects freedom of speech and of the press and is seen to be the protector of the most precious liberty of all: the right to express oneself and to participate in the democratic process. Free speech is seen to be the cornerstone of democracy and is interpreted to mean that any and all ideas may be heard including the right to criticize the government. As seen by the Supreme Court in West Virginia State Board of Education v Barnette (319 US 624 (1943)) free speech means that no official can prescribe what shall be orthodox in politics, religion or other matters of opinion. The Supreme Court in New York Times Co v Sullivan (376 US 254 (1964)) saw the central meaning of the First Amendment being that the 
debate on public issues should be uninhibited, robust and wide-open (see Lews Make No Law (1991) for a comprehensive discussion of New York Times Co $v$ Sullivan supra). Holmes J's memorable dissent in US $v$ Macintosh (283 US 605 (1931) 635) still rings true that the First Amendment guarantees freedom of both the ideas that people cherish and the thoughts they hate.

Uninhibited free speech, however, comes at a price as is illustrated in the so-called Skokie controversy. In that case the Federal Court of Appeal in Collin v Smith (528 F2d 1197 (1978)) upheld the right of a Nazi group to demonstrate in a predominantly Jewish community of Skokie, Illinois, and declared unconstitutional three municipal ordinances, including one that prohibited the dissemination of materials inciting hatred based on race, national origin or religion. (There is a sizeable literature on the Skokie affair of which Walker In Defense of American Liberties: A History of the ACLU (1990) and Downs Nazis in Skokie: Freedom, Community and the First Amendment (1985) can be recommended). The Supreme Court preferred not to hear the appeal of the Skokie case, letting the Federal Court of Appeal's decision stand. The decision in the Skokie case was predictable given the trend of First Amendment law in the United States and the commitment to free speech over the previous decades.

The Skokie affair was a prelude to the storm to come that exploded on university campuses throughout America. Due to shocking incidents of racism on university campuses, there was a proliferation of restrictive campus speech codes imposed by universities which led to a renewed nationwide debate on the First Amendment guarantee of free speech. Various university codes prohibited in expressive behaviour which created an intimidating, hostile, or demeaning environment for educational pursuits or participation in university-sponsored extra-curricular activities. When these campus speech codes reached federal courts, they met a resounding defeat and were declared unconstitutional on grounds of infringing the First Amendment (Doe v University of Michigan 721 F Supp 852 (ED Mich 1989); Hulshiger "Securing Freedom for Harassment Without Reducing Freedom of Speech: Doe v University of Michigan" 1991 lowa LR 383).

The "St Paul cross burning case", RAV v St Paul (505 US 377 (1992)) doomed the restrictive speech codes of universities. The RAV case involved a group of teenagers, including Robert Viktora, who put together a crudely made cross and burned it on the front lawn of an African American family. It could have been seen as a juvenile prank but there was no mistaking the meaning of the burning of the cross, the traditional symbol of the Ku Klux Klan. Being seen as a racist incident, it was taken seriously and Viktora was charged in a juvenile court under the city of St Paul's Bias-Motivated Crimes Ordinance which was a municipal ordinance. (Because Viktora was a juvenile at the time he was referred to as RAV - hence the name of the ultimate court case). The Supreme Court declared the St Paul ordinance unconstitutional. The decision was unanimous. Scalia $J$ writing for the majority held that the ordinance is precisely what the First Amendment forbids. RAV v St Paul supra reaffirmed an American tradition that afforded broad First Amendment protection for free speech that included offensive 
and hateful forms of expression (Henthoff Free Speech for Me - but Not for Thee (1992)).

In 2003 however, in Virginia v Black (538 US 343 (2003)) the Supreme Court held that a state may consistently with the First Amendment, ban cross burning if the latter is carried out with the intent to intimidate. In making this decision the Supreme Court intimated that genuine threats do not constitute protected free speech (Schauer "Intentions, Conventions and The First Amendment: The Case of Cross Burning" 2003 The Supreme Court Review 197 204). It is understandable that a prohibition on cross burning in the United States could be justified given the racial history of that country and that cross burning could be understood as being a credible threat of violence if done with the intent to intimidate. The majority of the Supreme Court in Virginia $v$ Black supra were of the view that the component of intimidation transformed the protection cross burning had acquired in RAV as being freedom of speech, into something that could be legally prohibited. Virginia $v$ Black supra, however, lends itself to various interpretations and only time will tell how it will influence the First Amendment's protection of freedom of speech.

\section{$6 \quad$ International instruments}

International and regional human rights instruments contain explicit and broad protection of freedom of expression but also contain explicit limitations on that right. Section 19 of the Universal Declaration of Human Rights (UDHR) (GA Res 217 Alll of 10 December 1948) provides "Everyone has the right to freedom of opinion and expression; this right includes freedom to hold opinions without interference and to seek, receive and impart information and ideas through any media and regardless of frontiers". A virtually identical provision is found in section 19 of the International Covenant of Civil and Political Rights (ICCPR) (1967 ILM 368) and section 10 of the European Convention for the Protection of Human Rights and Fundamental Freedoms (European Convention) (213 UNTS 221). Section 19 of the ICCPR, however, permits certain restrictions on freedom of expression when such restrictions are necessary for the rights or reputations of others or for the protection of national security or public order. Section 20 requires that any advocacy of national, racial or religious hatred that constitutes incitement to discrimination, hostility or violence shall be prohibited by law. Section 10 of the European Convention permits restrictions on freedom of expression when they are necessary for a democratic society, in the interests of national security, territorial integrity or public safety, for the protection of the reputation or the rights of others, for the prevention of crime or disorder or for the protection of health or morals.

Section 4 of the International Convention for the Elimination of All Forms of Racial Discrimination (CERD) (1966 ILM 352) requires that states parties shall declare an offence punishable by law, all dissemination of ideas based on racial superiority or hatred, incitement to racial discrimination, as well as acts of violence or incitement to such acts against any race or group or persons of another colour or ethnic origin. 
Section 9 of the African Charter on Human and People's Rights (hereinafter "the African Charter") (1982 ILM 58) states that every individual shall have the right to express and disseminate his opinions. It has been suggested that "within the law" - a so-called "clawback clause" undermines the freedoms set out in the African Charter and could arguably make the rights subject to domestic law and has consequently been severely criticized (Ankumah The African Commission on Human and Peoples' Rights (1996) 176). The African Commission has attempted to ameliorate these fears by suggesting that the term "within the law" should be restrictively interpreted and by suggesting that the term should be understood to refer to international, not domestic law (Dugard International Law: A South African Perspective (2011) 555). In Media Rights Agenda and Constitutional Rights Project $v$ Nigeria ((2000) 7 IHRR 565 par 66) the African Commission found that governments should avoid restricting rights and should have special regard to those rights protected by constitutional and international human rights law, one such right being the right to freedom of expression in section 9 of the African Charter (see Amnesty International v Zambia (2000) 7 IHRR 286).

\section{$7 \quad$ Conclusion}

It would appear that Wallis JA's restrictive interpretation of freedom of expression will find favour in Australia, where hate speech may be limited if it is likely to lead to violence. It would also find favour if recent developments in the United States are taken into account where cross burning may be banned if carried out with intent to intimidate and genuine threats are not seen as protected speech anymore. It is also in accordance with the ICCPR, which restricts freedom of expression if it advocates racial or religious hatred and if necessary to protect the rights of others. It would also accord with the European Convention, which allows restrictions on freedom of expression to protect the rights of others and CERD, which restricts freedom of expression if it incites racial discrimination. 